\title{
Analisis Penggunaan Google Classroom sebagai Media Pembelajaran
}

\author{
Aunurrahman', Mifta Rahman², Dewi Ismu Purwaningsih ${ }^{3}$ \\ 1,2 IKIP PGRI Pontianak, Indonesia \\ 3 Universitas Nahdlatul Ulama Kalimantan Barat, Indonesia \\ E-mail: mifta_rhmn@yahoo.co.id
}

\begin{tabular}{ll}
\hline Article Info & Abstract \\
\hline $\begin{array}{l}\text { Article History } \\
\text { Received: 2021-08-20 }\end{array}$ & $\begin{array}{l}\text { Google Classroom as learning media has been used in limited ways. This research } \\
\text { Revised: 2021-09-10 } \\
\text { Published: 2021-10-15 }\end{array}$ \\
$\begin{array}{l}\text { availability of internet and electricity to support the use of Google Classroom. The } \\
\text { research method was descriptive qualitative. The subject of research was the lecturers } \\
\text { in English Education Study Program of IKIP-PGRI Pontianak. The tools of data } \\
\text { Keywords: }\end{array}$ & $\begin{array}{l}\text { collecting used questionnaires; open and closed questionnaires. The data collected } \\
\text { Learning Application; } \\
\text { Google Classroom. }\end{array}$ \\
& $\begin{array}{l}\text { Gere analyzed and displayed used narrative text and tables. The result showed that } \\
\text { supports the teaching learning process in online class. There were good availability of } \\
\text { internet and electricity for the lecture to use Google Classroom in teaching. The further } \\
\text { research is hoped to be done to the students of university as the subject of research to } \\
\text { compare the use of Google Classroom as the media of teaching. }\end{array}$
\end{tabular}

\begin{tabular}{l}
\hline Artikel Info \\
\hline Sejarah Artikel \\
Diterima: 2021-08-20 \\
Direvisi: 2021-09-10 \\
Dipublikasi: 2021-10-15
\end{tabular}

Kata kunci:

Pembelajaran Daring; Aplikasi Pembelajaran; Google Classroom.

\begin{abstract}
Abstrak
Aplikasi Google Classroom sebagai platform pembelajaran daring belum banyak digunakan oleh dosen. Penelitian ini bertujuan untuk mengetahui persepsi dosen mengenai penggunaan Google Classroom dan dukungan layanan internet dan listrik yang tersedia. Bentuk penelitian ini adalah kualitatif deskriptif. Subjek penelitian adalah dosen yang mengajar pada program studi Pendidikan Bahasa Inggris IKIP-PGRI Pontianak. Teknik pengumpulan data dengan menggunakan kuesioner, yaitu kuesioner terbuka dan tertutup. Data yang telah terkumpul dianalisis dan disajikan dalam teks naratif dan tabel. Hasil penelitian menunjukkan bahwa Google Classsroom mudah untuk dipelajari dan digunakan serta terdapat fitur-fitur yang membantu dalam pelaksanaan langkah-langkah pembelajaran di kelas. Dukungan jaringan dan internet bagi bagi dosen untuk menggunakan aplikasi Google Classroom sangat baik. Penelitian selanjutnya diharapkan dapat menganalisis mahasiswa sebagai subjek penelitian sebagai bahan pertimbangan dalam penggunaan aplikasi sebagai media pembelajaran.
\end{abstract}

\section{PENDAHULUAN}

Penggunaan platform pembelajaran pada saat ini merupakan suatu kebutuhan, terlebih lagi pada masa pandemi Covid-19 yang tidak memungkinkan untuk menggunakan sistem belajar pembelajaran tatap muka. Platform pembelajaran telah banyak beredar di marketplace dan dapat digunakan secara gratis, antara lain Google Classroom, Edmodo, dan Moodle. Di antara aplikasi pembelajaran sejenis tersebut, Google Classroom lebih dikenal di Indonesia. Aplikasi Google Classroom ini telah diunduh lebih dari 100 juta pengguna dan masuk dalam 100 besar aplikasi teratas yang diunduh oleh pengguna pada Playstore, Google Classroom memiliki kelebihan, yaitu pembelajaran tidak terbatas pada ruang dan waktu. Pembelajaran saat ini, lebih diarahkan pada aktivitas modernisasi dengan harapan dapat membantu mahasiswa dalam mencerna materi perkuliahan secara interaktif, produktif, efektif, inspiratif, konstruktif, dan menyenangkan (Eliyarti et al., 2020). Adanya fitur-fitur pada Google Classroom yang memberikan kemudahan bagi dosen dan mahasiswa untuk melakukan pembelajaran tanpa melakukan tatap muka secara langsung akan mendukung sistem pembelajaran yang diperlukan saat ini.

Kelebihan yang diberikan oleh Google Classroom lainnya, yaitu keamanan aplikasi dengan menjaga kerahasiaan data yang tersimpan. Aplikasi Google Classroom juga tidak mengandung iklan dan tidak menggunakan data mahasiswa untuk kebutuhan iklan (Hapsari, 2019). Google Classroom merupakan satu di antara aplikasi yang diciptakan oleh Google 
sehingga Google Classroom dapat terhubung dengan aplikasi lainnya, yaitu Gmail, Google Drive, dan Youtube. Dengan demikian, materi pembelajaran yang akan ditampilkan pada Google Classroom dapat langsung ditautkan dengan link.

Penggunaan aplikasi Google Classroom sebelum pandemi Covid-19 belum banyak digunakan karena pembelajaran masih dilakukan secara tatap muka dan akses internet di Kalimantan Barat yang belum merata. Penggunaan Google Classroom yang dilakukan dosen masih tergolong baru dilakukan selama 2 tahun terakhir. Oleh karena itu, penelitian ini bertujuan untuk mengetahui persepsi dosen mengenai penggunaan Google Classroom dan dukungan layanan internet dan listrik yang tersedia.

\section{METODE PENELITIAN}

Sesuai dengan tujuan penelitian, maka metode yang digunakan pada penelitian ini adalah kualitatif deskriptif. Dalam penelitian ini, akan diberikan gambaran mengenai status atau karakteristik dari fenomena mengenai penggunaan Google Classroom, subjek penelitian adalah dosen yang mengajar pada Program Studi Pendidikan Bahasa Inggris IKIP-PGRI Pontianak. Teknik pengumpulan data dengan menggunakan kuesioner, yaitu kuesioner terbuka dan tertutup. Data yang telah terkumpul dianalisis dan disajikan dalam teks naratif dan tabel untuk memudahkan. Setelah semua data dianalisis, maka dilakukan penarikan kesimpulan.

\section{HASIL DAN PEMBAHASAN}

Penggunaan Google Classroom dalam pembelajaran digunakan oleh dosen untuk keperluan mengajar. Proses mengajar ini antara lain berdiskusi, membagikan materi dan membuat soal. Sebanyak 57,14\% dosen setuju bahwa Google Classroom dapat menggantikan pertemuan tatap muka di kelas. Semua fitur di dalam Google Classroom dimanfaatkan oleh dosen untuk pengajaran di kelas secara daring. Adapun fitur-fitur yang terdapat pada Google Classroom antara lain:

1. Membuat pengumuman atau berinteraksi dengan mahasiswa, pada fitur ini dosen dapat menuliskan pengumuman, memilih mahasis-wa yang menerima pengumuman, dan menjadwalkan waktu pengumuman ditampilkan.

2. Membuat tugas untuk mahasiswa. Pada fitur ini, dosen dapat memeriksa proses mahasiswa yang sudah mengerjakan dan belum mengerjakan.

3. Membuat pertanyaan/kuis untuk mahasiswa.

4. Menggunakan kembali aktivitas yang dituliskan pada kegiatan sebelumnya.

Hasil penelitian terhadap dosen dalam menggunakan platform Google Classroom dalam pembelajaran menunjukkan bahwa semua dosen sudah pernah menggunakan Google Classroom. Penggunaan Google Classroom oleh dosen menunjukkan adanya variasi lamanya penggunaan, yaitu antara 1 hingga 2 tahun. Hal ini menunjukkan bahwa penggunaan Google Classroom baru mulai dilakukan pada masa pandemi Covid-19. Sejalan dengan hal tersebut, Mastoni dan Rahmawati (2019) juga menyebutkan bahwa aplikasi Google Classroom belum banyak diketahui oleh sebagian besar pendidik di Indonesia.

Adanya perubahan dalam sistem pembelajaran dengan menggunakan Google Classroom akan membawa pengaruh pada penggunanya, yaitu dosen. Penerimaan terhadap teknologi terbagi menjadi dua, yaitu penerimaan kegunaannya dan penerimaan kemudahan dalam menggunakan. Teknologi akan diterima dengan baik jika memenuhi unsur manfaat dan kemudahan (Muslik, 2019). Persepsi dosen dalam penggunaan Google Classroom sebagai teknologi baru untuk pembelajaran daring dapat dilihat pada tabel berikut.

Tabel 1. Persepsi Dosen terhadap Penggunaan Google Classroom

\begin{tabular}{|c|c|c|c|}
\hline \multirow[t]{2}{*}{ No } & \multirow[t]{2}{*}{ Deskripsi Persepsi Dosen } & \multicolumn{2}{|c|}{$\begin{array}{l}\text { JML (dalam } \\
\text { persentase) }\end{array}$} \\
\hline & & Ya & Tidak \\
\hline 1 & $\begin{array}{l}\text { Google Classroom memberikan } \\
\text { kemudahan dalam } \\
\text { menyampaikan materi } \\
\text { perkuliahan. }\end{array}$ & 100 & 0 \\
\hline 2 & $\begin{array}{l}\text { Google Classroom memberikan } \\
\text { kemudahan dalam memberikan } \\
\text { pengumuman dan tugas. }\end{array}$ & 100 & 0 \\
\hline 3 & $\begin{array}{l}\text { Google Classroom dapat } \\
\text { menggantikan pertemuan tatap } \\
\text { muka di kelas. }\end{array}$ & 57,14 & 42,86 \\
\hline 4 & $\begin{array}{l}\text { Mahasiswa menjadi lebih aktif } \\
\text { dalam pembelajaran dengan } \\
\text { menggunakan Google Classroom. }\end{array}$ & 42,86 & 57,14 \\
\hline 5 & $\begin{array}{l}\text { Dosen memerlukan strategi } \\
\text { khusus dalam mengajar } \\
\text { menggunakan Google Classroom. }\end{array}$ & 71,43 & 28,57 \\
\hline 6 & $\begin{array}{l}\text { Dosen memahami semua fitur- } \\
\text { fitur yang terdapat dalam Google } \\
\text { Classroom. }\end{array}$ & 100 & 0 \\
\hline 7 & $\begin{array}{l}\text { Menu pada Google Classroom } \\
\text { mudah digunakan. }\end{array}$ & 100 & 0 \\
\hline
\end{tabular}




\begin{tabular}{clcc}
\hline \hline 8 & $\begin{array}{l}\text { Tampilan pada Google Classroom } \\
\text { sangat jelas dan mudah } \\
\text { dipahami. }\end{array}$ & 100 & 0 \\
\hline 9 & $\begin{array}{l}\text { Penggunaan Google Classroom } \\
\text { mudah dipelajari. }\end{array}$ & 100 & 0 \\
\hline 10 & $\begin{array}{l}\text { Google Classroom mudah untuk } \\
\text { diakses. }\end{array}$ & 100 & 0 \\
\hline 11 & $\begin{array}{l}\text { Google Classroom mempercepat } \\
\text { dalam pengumpulan tugas } \\
\text { mahasiswa. }\end{array}$ & 71,43 & 28,57 \\
\hline
\end{tabular}

Dari Tabel diatas dapat diketahui bahwa Google Classroom memberikan kemudahan bagi dosen dalam menyampaikan materi perkuliahan, memberikan pengumuman, dan memberikan tugas kepada mahasiswa, desain Google Classroom dibuat untuk memudahkan pengguna dengan fitur penugasan tanpa kertas (paperless) sehingga dosen dapat mengelola kelas, tugas, nilai, dan memberikan masukan kepada siswa secara langsung (Rachayu dan Selviani, 2020). Menu pada Google Classroom juga mudah digunakan dan tampilannya sangat jelas dan mudah dipahami serta mudah diakses. Sebagai tambahan, fitur-fitur di Google Classroom mudah untuk dipelajari sehingga semua dosen telah memahami fitur-fiturnya tanpa harus mengikuti pelatihan cara mengoperasikannya.

Google Classroom sebagai sebuah alat, keefektifan penggunaannya tergantung pada kreativitas penggunaan dari dosen sendiri. Pada Tabel 1 dapat dilihat bahwa sebanyak 57,14\% dosen tidak setuju bahwa mahasiswa menjadi lebih aktif dalam pembelajaran dengan menggunakan Google Classroom. Dosen harus lebih berinovasi dan menarik minat mahasiswa dalam menyajikan materi agar tidak monoton (Lestari, 2021). Minat mahasiswa merupakan faktor pendukung keberhasilan belajar. Seseorang yang memiliki motivasi akan belajar lebih giat daripada orang yang tidak memiliki motivasi (Rahman, M., Purwaningsih, D.I., \& Ruhama, 2018), Pembelajaran dengan menggunakan Google Classroom bagi sebagian besar dosen pada penelitian ini memerlukan strategi khusus. Adapun strategi yang digunakan oleh dosen dalam mengaplikasikan Google Classroom, yaitu:

1. Instruksi yang dituliskan pada Google Classroom sehingga mudah dipahami dan dilaksanakan oleh mahasiswa.

2. Materi yang dikumpulkan ke dalam satu file dengan ukuran yang tidak besar sehingga memudahkan mahasiswa ketika mengunduh file materi tersebut.

3. Alat dan koneksi jaringan internet yang memadai.
Fitur-fitur yang disediakan oleh Google Classroom tidak semuanya dimanfaatkan oleh dosen. Sebagian besar dosen sudah memanfaatkan fitur-fitur yang terdapat pada Google Classroom secara optimal. Sebaliknya, sebanyak 14,28\% dosen menggunakan Google Classroom untuk berbagi instruksi dan materi pembelajaran dan sebanyak 14,28\% dosen lainnya menggunakan Google Classroom pada fitur tugas. Fitur ini dimanfaatkan oleh dosen sebagai sarana untuk mengirim tugas kepada mahasiswa, mengumpulkan tugas mahasiswa, mengirimkan soal ujian tengah semester dan mengumpulkan jawabannya, serta mengirimkan soal ujian akhir semester dan mengumpulkan jawabannya.

Fitur tugas yang disediakan oleh Google Classroom mudah untuk digunakan. Pengiriman tugas melalui Google Classroom mempermudah mahasiswa karena mahasiswa tidak perlu mencetak tugas serta dapat membuat mahasiswa memiliki manajemen waktu dengan adanya fitur rentang waktu pengumpulan tugas (Nurhusna, 2020, Utami, 2019). Pada penelitian ini, sebanyak $71,43 \%$ dosen setuju bahwa Google Classroom mempercepat dalam pengumpulan tugas mahasiswa. Adapun penggunaan fitur tugas dalam Google Classroom dapat dilihat pada Gambar berikut:

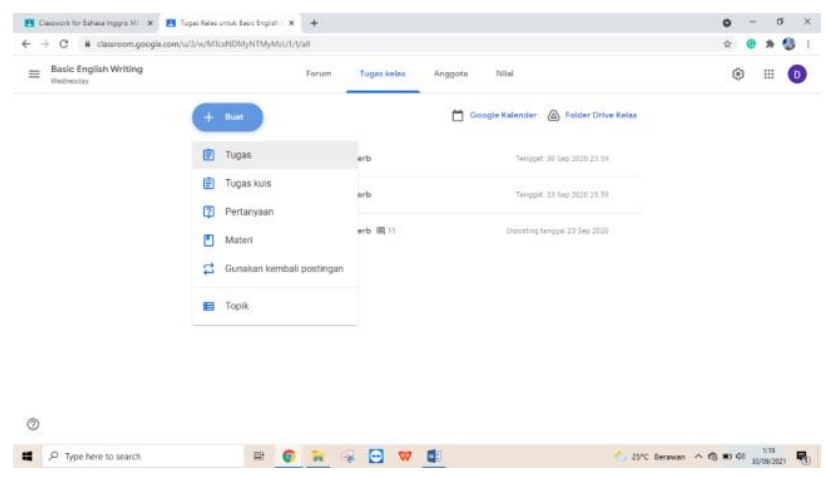

Gambar 1. Tampilan fitur tugas pada Google Classroom

Gambar diatas merupakan Tampilan fitur tugas pada Google Classroom yang bertujuan untuk menunjukkan bahwa teknik membagikan tugas, dosen dapat melakukanya dengan mengklik pada menu tugas kelas, kemudian mengklik tombol menu buat, dan mengklik tombol tugas. Selanjutnya, menu tampilan pada Google Classroom akan tampak seperti gambar Tampilan detail menu tugas pada Google Classroom berikut: 


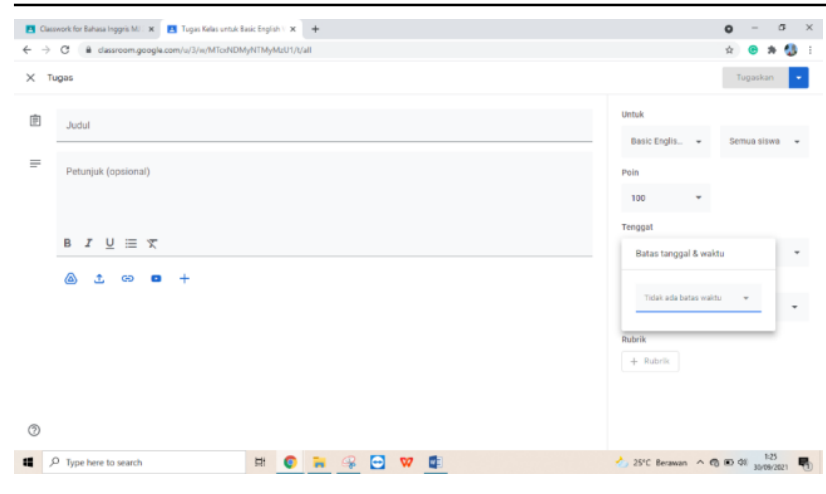

Gambar 2. Tampilan detail menu tugas pada Google Classroom

Gambar diatas menunjukkan tampilan isi menu tugas secara detail. Pada menu tugas ini, dosen mengisi judul tugas yang diberikan kepada mahasiswa. Dosen dapat menuliskan petunjuk pengerjaan tugas pada kotak yang disediakan di bawah judul. Menu petunjuk pengerjaan soal ini tidak wajib diisi oleh dosen. Selanjutnya, soal yang diberikan kepada mahasiswa sebagai bentuk tugas dapat diunggah dari penyimpanan drive atau komputer. Selain mengunggah, dosen juga dapat melakukan tautan link atau Youtube, Pada menu sebelah kanan di Gambar 2, dapat dilihat bahwa tugas yang diberikan oleh dosen dapat diatur untuk ditujukan kepada mahasiswa yang dipilih. Dosen juga dapat menuliskan jumlah poin atau nilai maksimal yang mahasiswa dapatkan ketika mengerjakan semua soal dan jawabannya benar. Penugasan ini dapat diatur tenggat batas dan waktu pengumpulannya. Jika dosen mengatur batas tenggat waktu pengumpulan tugas, maka pada akun Google Classroom mahasiswa akan diatur pengingat tenggat waktu pengumpulan tugas. Pengumpulan tugas yang terlambat dilakukan oleh mahasiswa akan terangkum pada aktivitas mahasiswa pada pengerjaan tugas tersebut.

Aktivitas mahasiswa dalam Google Classroom terekam secara teratur dan terorganisir. Fitur Google Classroom dapat menampilkan notifikasi aktivitas tugas yang dikumpulkan mahasiswa, yaitu tugas yang diberikan oleh dosen, tugas mahasiswa yang sudah selesai diserahkan, atau tugas mahasiswa yang terlambat mengumpulkan. Adanya notifikasi ini dapat digunakan oleh dosen untuk meningkatkan mutu pembelajaran (Rahma dan Arista, 2021). Dengan demikian, dosen menjadi lebih mudah dalam melakukan monitoring pada proses pembelajaran mahasiswa, Fitur-fitur yang terdapat pada Google Classroom akan dapat diakses dengan lancar dengan didukung oleh jaringan internet yang baik. Pada penelitian ini, semua dosen dapat mengakses Google Classroom dengan baik tanpa adanya kendala pada jaringan. Kendala jaringan internet yang tidak lancar dapat terjadi pada mahasiswa yang berada pada daerah yang belum memiliki akses internet yang memadai. Di Indonesia, terdapat banyak daerah-daerah yang belum dijangkau oleh fasilitas internet (Suparjan, dkk., 2021).

Selain jaringan internet, ketersediaan daya listrik juga faktor utama untuk mengakses Google Classroom. Di Kalimantan Barat, masih ada daerah-daerah yang belum memberikan akses listrik secara optimal. Upaya peningkatan akses listrik yang merata di Kalimantan Barat masih menjadi tujuan dan sasaran rencana pembangunan di Kalimantan Barat hingga tahun 2023 (Kanwil Ditjen Perbendaharaan Provinsi Kalimantan Barat, 2020). Listrik yang belum merata merupakan kendala utama dalam penerapan Google Classroom sebagai media pembelajaran. Oleh karena itu, dosen perlu melihat kondisi mahasiswa dan melakukan monitoring terhadap mahasiswa yang jarang aktif pada diskusi atau terlambat mengumpulkan tugas pada Google Classroom.

\section{SIMPULAN DAN SARAN}

\section{A. Simpulan}

Hasil penelitian menunjukkan bahwa penggunaan Google Classroom dalam pembelajaran daring yang dilakukan oleh dosen memberikan kemudahan dalam dalam menyampaikan materi perkuliahan, memberikan pengumuman dan memberikan tugas kepada mahasiswa. Menu dan fitur-fitur yang terdapat dalam Google Classroom juga mudah untuk digunakan dan dipelajari. Penggunaan Google Classroom dapat menggantikan pembelajaran tatap muka di kelas bagi sebagian besar dosen dan diperlukan strategi dalam menerapkan aplikasi ini. Dukungan jaringan internet dan listrik bagi dosen untuk menggunakan aplikasi Google Classroom sangat baik karena dosen tidak pernah mengalami kendala pada internet dan listrik.

\section{B. Saran}

Penelitian yang dilakukan pada program studi pendidikan bahasa Inggris ini masih terbatas dilakukan pada dosen. Penelitian selanjutnya dapat dikembangkan dengan subjek penelitian yaitu mahasiswa sehingga diketahui persepsi dan kendala yang dihadapi oleh mahasiswa dalam menggunakan Google Classroom. Dengan demikian, penelitian ini 
akan berguna bagi dosen dan pendidik lainnya dalam memilih menggunakan media media yang dapat meningkatkan proses pembelajaran, baik secara daring maupun luring.

\section{DAFTAR RUJUKAN}

Eliyarti, E., Rahayu, C., \& Zakirman, Z. (2020). Tinjauan Kontribusi Google Classroom Dalam Mendukung Perkuliahan Kimia Dasar. Jurnal Pendidikan Kimia Indonesia, 4(1), 32-39. https://doi.org/10.23887/jpk.v4i1.24299

Hapsari, M. J. (2019). Penggunaan Aplikasi Google Classroom Dalam Pembelajaran Matematka Tipe Think Pair Share Di Smkn 3 Banjarmasin. 153-161.

Kanwil Ditjen Perbendaharaan Provinsi Kalimantan Barat. (2020). Kajian Fiskal Regional Tahun 2020. Pontianak: Kemenkeu.

Lestari, I. D. (2021). Pemanfaatan Aplikasi Google sebagai Media Pembelajaran pada Mata Kuliah Pancasila. SAP (Susunan Artikel Pendidikan), 6(1), 112-117. https://doi.org/10.30998/sap.v6i1.9312

Mastoni, \& Rahmawati. (2019). Desain Pembelajaran Bahasa Inggris Melalui Google Classroom. Prosiding Seimanar Nasional Pendidikan Program Pascasarjana Universitas PGRI Palembang, 701-712

Muslik, A. (2019). Google classroom sebagai alternatif digitalisasi pembelajaran matematika di era revolusi industri 4.0. 246255.

Nurhusna. (2020). Google Classroom sebagai
Media Pembelajaran pada Mata Kuliah Teks Bahasa Indonesia. Prosiding Seminar Daring Nasional: Pengembangan Kurikulum Merdeka Belajar Program Studi Pendidikan Bahasa Indonesia. 52 - 57.

Rachayu, I., \& Selviani, D. (2020). Optimalisasi sistem kelas virtual berbasis google classroom dan hipnoterapi. Journal of Dehasen Educational Review, 1(3), 104-109. https://jurnal.unived.ac.id/index.php/jder/ article/view/1229

Rahma, A. A., \& Arista, H. (2021). Analisis Penerapan Google Classroom Untuk Meningkatkan Mutu Pembelajaran Online Di Masa Pandemi Covid-19. Pedagogy: Jurnal Ilmiah Ilmu Pendidikan, 8(1), 88-95. https://doi.org/10.51747/jp.v8i1.730

Rahman, M., Purwaningsih, D.I., \& Ruhama, U. (2018). Pena Kreatif : PENA KREATIF Jurnal Pendidikan, 8(2), 155-165. http://openjurnal.unmuhpnk.ac.id/index.ph $\mathrm{p} / \mathrm{IPK} /$ article/view/1396

Suparjan, E. (2021). Respon Mahasiswa Terhadap Pembelajaran Menggunakan Google Classroom Di Masa Pendemi Covid19 Pada Mata Kuliah Konsep Dasar Pkn. Jurnal Teknologi Pendidikan (JTP), 14(1), 51. https://doi.org/10.24114/itp.v14i1.23406

Utami, R. (2019). Analisis Respon Mahasiswa terhadap Penggunaan Google Classroom pada Mata Kuliah Psikologi Pembelajaran Matematika. Prisma, Prosiding Seminar Nasional Matematika ISSN 2613-9189, 2, 498-502.

https://journal.unnes.ac.id/sju/index.php/p risma/article/view/29040 